Counsellia: Jurnal Bimbingan dan Konseling 8 (2) 114-121 | November 2018

Copyright (C2017 Universitas PGRI Madiun

ISSN: 2088-3072 (Print) / 2477-5886 (Online)

Available online at: http://e-journal.unipma.ac.id/index.php/JBK

DOI: 10.25273/counsellia.v8i2.2944

\title{
Self-efficacy level to recover from addiction in substance users in The Center for Drug Rehabilitation
}

\author{
Agus Supriyanto ${ }^{1)}$, Nurlita Hendiani ${ }^{2)}$ \\ ${ }^{1}$ Universitas Ahmad Dahlan, Yogyakarta \\ agus.supriyanto@bk.uad.ac.id \\ ${ }^{2}$ Balai Besar Rehabilitasi, Badan Narkotika Nasional, Bogor \\ nurlitahen@gmail.com
}

\begin{abstract}
Abstrak
Self-efikasi adalah prediktor bagi individu dengan Gangguan Penyalahgunaan Zat (GPZ) untuk sembuh dari kecanduan obat. Perlunya pengukuran untuk mengetahui self-efikasi dari individu dengan GPZ. Tujuan penelitian untuk mengetahui tingkat self-efikasi kepada orang dengan GPZ untuk pulih dari kecanduan narkoba pada dimensi tingkat, dimensi kekuatan, dan dimensi general. Penelitian ini menggunakan pendekatan deskriptif. Intrument penelitian melalui skala self-efikasi dengan subejk $N=217$. Subyek penelitian adalah pengguna zat yang menjalani program rehabilitasi narkoba di Pusat Rehabilitasi Narkoba, Indonesia. Subyek penelitian memiliki 217 dengan jenis kelamin laki-laki (Reentry, HOC, Faith, Care, and Hope) dan jenis kelamin perempuan (Perempuan). Analisis deskriptif untuk mengetahui tigkat self efikasi pada individu dengan GPZ. Dimensi level pada level tinggi. Berbeda dengan dimensi level, bahwa dalam dimensi kekuatan individu dan generalitas individu untuk memulihkan memiliki tingkat yang rendah. Perbedaan dimensi tingkat dengan dimensi kekuatan dan dimensi umum karena dimensi tingkat terbatas pada perasaan individu untuk dapat pulih dari kecanduan narkoba, sedangkan dimensi kekuatan dan pusat umum pada aspek kognitif, afektif, dan psikomotor. Konselor dapat merancang strategi konseling untuk mengembangkan self-efficacy dan mencegah kekambuhan.
\end{abstract}

Kata Kunci: efikasi diri, kecanduan, rehabilitasi narkoba

\begin{abstract}
Self-efficacy is a predictor for individuals with Substance Abuse Disorders (SAD) to recover from drug addiction. The need for measurements to determine the efficacy of individuals with SAD. The aim of the study was to determine the level of self-efficacy of people with $S A D$ to recover from drug addiction in the level dimensions, strength dimensions, and general dimensions. This study uses a descriptive approach. The research instrument was self-efficacy scale with subject $N=217$. Research subjects were substance users undergoing a drug rehabilitation program at the Drug Rehabilitation Center, Indonesia. Research subjects had 217 with male gender (Re-entry, HOC, Faith, Care, and Hope) and female gender (Female). Quantitative descriptive analysis to determine the level of self efficacy in individuals with SAD. The level dimension at a high level. Unlike the level dimension, that in the dimension of individual strength and individual generality to recover has a low level. Level dimension differences with the dimensions of strength and general dimensions because the level dimension is limited to individual feelings to be able to recover from drug addiction, while the dimensions of strength and general center on cognitive, affective, and psychomotor aspects. The counseling strategy of addiction counselors is needed to prevent relapse of drug addiction.
\end{abstract}

Keywords: self efficacy, addiction, drugs rehabilitation 



\section{INTRODUCTION}

Drugs are prohibited substances in the international world (Stevenson, 2010). Three types of drugs are illegal and legal drugs, medicines for mental health, and a category of substances cognition enhancers that might enhance the performance of the brain (Horn, Barnes, Brownsword, Deakin, Gilmore, Hickman, ... \& Wolff, 2010). Consumption of an increasing amount of drugs can affect the individual's health, socials life, personals life (Ersche, Jones, Williams, Turton, Robbins, \& Bullmore, 2012) and damages of the body such as oral cavity, lungs, liver, brain, and heart (Saini, Gupta, \& Prabhat, 2013). Individuals who have drug dependence need a healing process in various ways. First, effects of drugs have great potential for treating drug abuse (Shen, Orson, \& Kosten, 2012). Second, Internet technology and gadgets affect prevention, care and recovery from disturbances (Marsch, 2012). Then, the service model in individuals with substance use disorders needs to provide short-term services, focusing on intense symptoms is not appropriate to overcome the problem (Laudet\& White, 2010).

The phenomenon, behavioral intervention has very poor results with more than $80 \%$ of patients returning to drug use (Bart, 2012). Implications of drug abuse prevention strategies and strategies involving the inhibition process of the prefrontal cortex that can reduce related behavior, including effective public services, cognitive training, physical activity, direct current stimulation, feedback control training and pharmacotherapy (Perry, Joseph, Jiang, Zimmerman, Kelly, Darna, ... \& Bardo, 2011). Given the difficulties in identifying those at risk of relapse (Emsley, Chiliza, Asmal, \& Harvey, 2013). Relapse is a return to a poor initial behavior pattern (Reber\& Reber, 2010).

The former drug abuses abilities to overcome all obstacle in life while achieving life that is free from drugs would be influenced by self-efficacy (Ibrahim, Kumar, \& Samah, 2011). Self-efficacy is the belief that one has the ability to implement the behaviors needed to produce a desired effect (Kadden\& Litt, 2011). Treatment to adults merit clinical attention because of lower selfefficacy throughout treatment (Greenfield, Venner, Kelly, Slaymaker, \& Bryan, 2012). Knowledge of the level of selfefficacy in substance abuse disorders (SAD) as part of an evaluation of a rehabilitation program.

Measurement of the level of self-efficacy through various indicators and dimensions. Indicators of self-efficacy scales to recover from addiction through three dimensions, ie (1) level dimension, (2) general dimension, and (3) strength dimension (Supriyanto\& 
Hendiani, 2018). Level dimension, general dimension, and strength dimension for substance users is needed for the development of self confidence to recover from addiction. Counselors provide services to help potential client recovery psychological, motivational, emotional, and career development. The process of implementing a counseling approach for people with SAD is very important to undergo a drug rehabilitation program (Supriyanto, 2017).

\section{RESEARCH METHOD}

Research method with quantitative descriptive approach. The purpose of this study was to determine the level of self-efficacy in substance users who have problems with drug abuse disorders. Research subjects were substance users undergoing a drug rehabilitation program at the Drug Rehabilitation Center, Indonesia. Research subjects had 217 with male gender (Re-entry, HOC, Faith, Care, and Hope) and female gender (Female).

The self-efficacy dimension for recovery is the level dimension, general dimension, and strength dimension. Measuring tool using self-efficacy scale. Descriptive analysis to determine the level of self-efficacy of level dimension, general dimension, and strength dimension.

\section{RESULT AND DISCUSSION}

The findings of the self-efficacy evaluation of users undergoing rehabilitation programs in Indonesia at low levels (2.52 on a scale of 4). $2.76 \%$ have a very high level of selfefficacy to recover from SAD and $8.29 \%$ who have a high level of selfefficacy to recover from SAD. While $43.32 \%$ had a low level of selfefficacy to recover from SAD and $45.62 \%$ had very low level of selfefficacy to recover from SAD. Craving and quality of life affect the desire to recover (Tiffany, Friedman, Greenfield, Hasin, \& Jackson, 2012). Self-stigma was significantly related to reduced self-efficacy (Schomerus, Corrigan, Klauer, Kuwert, Freyberger, \& Lucht, 2011).

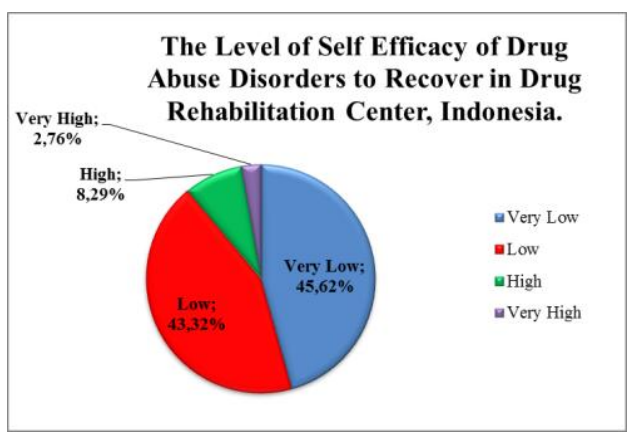

Figure 1. The level of Self-efficacy to Recover from Substance Abuse Disorders

Analysis of the level of selfefficacy has also revealed a threedimensional percentage of selfefficacy. Level of dimension level or desire to recover, level of strength to recover, and level of generality. Because self-efficacy is also about belief in one's ability to organize and 
implement the program of action necessary to manage situation (Bandura, 2009).

First, the level dimension has a connection with confidence to mobilize rehabilitation efforts well, able to produce outputs to achieve healing, be able to face existing challenges, be able to complete rehabilitation, and rehabilitate on time. The findings reveal that feelings possessed individually at the level dimension at a high level. 2\% of individuals have very low levels, $18 \%$ of individuals have low levels, $25 \%$ of individuals have a high level, and most individuals at very high levels or $55 \%$. Despite the increased interest, but the identity preferences may be a strategy to reduce relapse among people with addictive behavior problems (Buckingham, Frings, \& Albery, 2013).

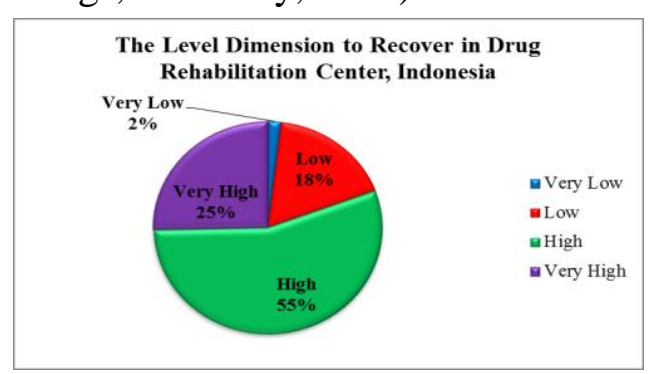

Figure 2. The level Dimension to Recover from Substance Abuse Disorders

Unlike the level dimension, that in the dimension of individual strength to recover has a low level. Only $4 \%$ have a very high strength to recover and $18 \%$ have a relatively high strength to recover. Most substance users who undergo rehabilitation programs have a low strength to recover with a percentage of $65 \%$. While $13 \%$ have very low levels or don't have the strength to recover. Addiction counselors need to focus on relevant and effective treatment, especially important weaknesses in recovery discourses (Neale, Tompkins, Wheeler, Finch, Marsden, Mitcheson, ... \& Strang, (2015).

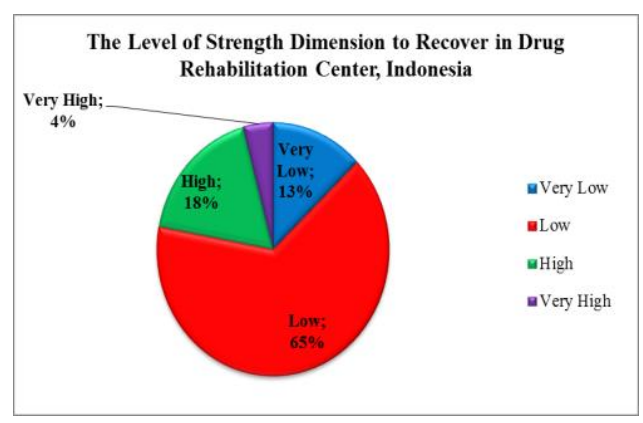

Figure 3. The level of Strength Dimension to Recover from Substance Abuse Disorders

Dimensional measurements have measured the power of individuals in achieving the recovery as well as the feelings and beliefs of individuals that the selected action will achieve recovery. The main strength in the recovery process is the active involvement of the community in group counseling activities and peer support activities (Best\& Lubman, 2012). Skilled care options to clients who are addicted crucial to the outcome of treatment clients from addiction counselor (Harrawood, McClure, \& Nelson, 2011). 


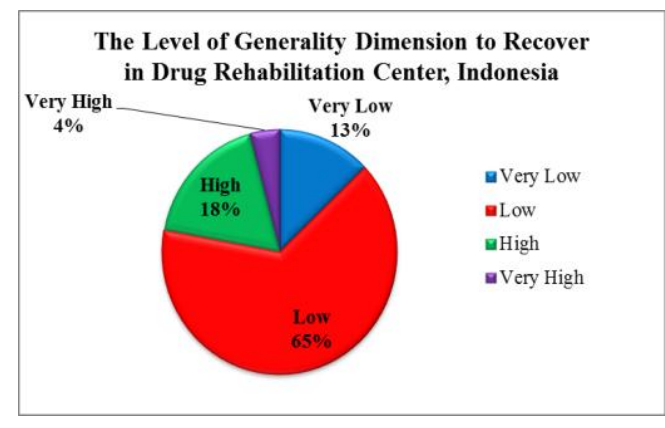

Figure 4. The level of Generality Dimension to Recover from Substance Abuse Disorders

The last dimension is generality dimension. The dimension of generality reveals feeling confident to able to do rehabilitation that can be completed by others, to development cognition, affection, and psychomotor, and the ability to complete rehabilitation with selfcharacteristic. The result is $4 \%$ has a very high level and $18 \%$ has a high level. While $65 \%$ of individuals have low ability levels, and 13\% have very low abilities. Individual inability to change because of the increases in negative emotional states, dysphoric, and stress (Koob \& Volkow, 2016). Addiction is a chronic disorder relapse in people who need help. (Sellman, 2010).

A counseling approach needs to be carried out by addiction counselors to foster self-efficacy in drug rehabilitation programs. The approach to various drug addiction problems, such as consultation and education in drug problems as the solution to drug abuse disorders
(Yoshimura \& Higuchi, 2015). The medical approach more effective than criminal approach in reducing addiction (Volkow, Baler, \& Goldstein, 2011). Social approach and its impact on behaviors as the form of recovery capital for assessing individual progress on a recovery journey (Groshkova, Best, \& White, 2013). Islamic guidance also as a solution to mental health development (Supriyanto, 2016). Behavior therapies with meditations to addiction settings (Young, DeLorenzi, \& Cunningham, 2011).

The counseling strategy of addiction counselors is needed to prevent relapse of drug addiction. Information from clients regarding the outcomes of counseling has a positive correlation to build relationships between counselors and clients (Geller, Greenberg, \& Watson, 2010). Humane treatment in the setting of more enlightened comprehensive (Kandall, 2010).

\section{CONCLUSION}

Self-efficacy is a predictor of recovery for users undergoing drug rehabilitation at the Indonesian Center for Drug Rehabilitation. Measurement of self-efficacy to determine individual beliefs to recover from substance abuse disorders. High dimensions, dimensions of strength, and general dimensions are the main foundation of the self-efficacy variable.

The findings have shown that self-efficacy evaluation of users 
undergoing rehabilitation programs in Indonesia at low levels. Feelings possessed individually at the level dimension at a high level. Unlike the level dimension, that in the dimension of individual strength and individual generality to recover has a low level. Level dimension differences with the dimensions of strength and general dimensions because the level dimension is limited to individual feelings to be able to recover from drug addiction, while the dimensions of strength and general center on cognitive, affective, and psychomotor aspects to recover from drug addiction.

\section{REFERENCES}

Bandura, A (ed). (2009). Self Efficacy in Changing Society. Cambridge: Cambridge University Press

Bart, G. (2012). Maintenance medication for opiate addiction: the foundation of recovery. Journal of addictive diseases, 31(3), 207-225.

Best, D. W., \& Lubman, D. I. (2012). The recovery paradigm: A model of hope and change for alcohol and drug addiction. Australian family physician, 41(8), 593.

Buckingham, S. A., Frings, D., \& Albery, I. P. (2013). Group membership and social identity in addiction recovery. Psychology of Addictive Behaviors, 27(4), 1132.

Emsley, R., Chiliza, B., Asmal, L., \& Harvey, B. H. (2013). The nature of relapse in schizophrenia. $B M C$ psychiatry, 13(1), 50.
Ersche, K. D., Jones, P. S., Williams, G. B., Turton, A. J., Robbins, T. W., \& Bullmore, E. T. (2012). Abnormal brain structure implicated in stimulant drug addiction. Science, 335(6068), 601-604.

Geller, S. M., Greenberg, L. S., \& Watson, J. C. (2010). Therapist and client perceptions of therapeutic presence: The development of a measure. Psychotherapy Research,20(5), 599-610.

Groshkova, T., Best, D., \& White, W. (2013). The A ssessment of $R$ ecovery $\mathrm{C}$ apital: Properties and psychometrics of a measure of addiction recovery strengths. Drug and Alcohol Review, 32(2), 187-194.

Greenfield, B. L., Venner, K. L., Kelly, J. F., Slaymaker, V., \& Bryan, A. D. (2012). The impact of depression on abstinence selfefficacy and substance use outcomes among emerging adults in residential treatment. Psychology of Addictive Behaviors, 26(2), 246.

Harrawood, L. K., McClure, C. C., \& Nelson, J. (2011). Using experiential activities to prepare counselors-in-training to understand the power of cravings when addressing clients with addiction. Journal of Creativity in Mental Health, 6(2), 105-117.

Horn, G., Barnes, J., Brownsword, R., Deakin, J. F. W., Gilmore, I., Hickman, M., ... \& Wolff, J. (2010). Brain science, addiction and drugs. Project Report. The Academy of Medical Sciences, London, UK.

Kadden, R. M., \& Litt, M. D. (2011). The role of self-efficacy in the treatment of substance use 
disorders. Addictive

behaviors, 36(12), 1120-1126.

Kandall, S. R. (2010). Women and drug addiction: a historical perspective. Journal of addictive diseases, 29(2), 117-126.

Koob, G. F., \& Volkow, N. D. (2016). Neurobiology of addiction: a neurocircuitry analysis. The Lancet Psychiatry, 3(8), 760773.

Laudet, A. B., \& White, W. (2010). What are your priorities right now? Identifying service needs across recovery stages to inform service development. Journal of Substance Abuse Treatment, 38(1), 51-59.

Marsch, L. A. (2012). Leveraging technology to enhance addiction treatment and recovery. Journal of addictive diseases, 31(3), 313-318.

Neale, J., Tompkins, C., Wheeler, C., Finch, E., Marsden, J., Mitcheson, L., ... \& Strang, J. (2015). "You're all going to hate the word 'recovery'by the end of this": Service users' views of measuring addiction recovery. Drugs: $\quad$ education, prevention and policy,22(1), 26-34.

Perry, J. L., Joseph, J. E., Jiang, Y., Zimmerman, R. S., Kelly, T. H., Darna, M., ... \& Bardo, M. T. (2011). Prefrontal cortex and drug abuse vulnerability: translation to prevention and treatment interventions. Brain research reviews, 65(2), 124 149.

Reber, A.S., \& Reber, E.S. (2010). Kamus Psikologi. Yogyakarta: Pustaka Pelajar.

Saini, G. K., Gupta, N. D., \& Prabhat, K. C. (2013). Drug addiction and periodontal diseases. Journal of Indian
Society

Periodontology, 17(5), 587.

Schomerus, G., Corrigan, P. W., Klauer, T., Kuwert, P., Freyberger, H. J., \& Lucht, M. (2011). Selfstigma in alcohol dependence: consequences for drinkingrefusal self-efficacy. Drug and alcohol dependence, 114(1), 1217.

Sellman, D. (2010). The 10 most important things known about addiction. Addiction, 105(1), 613.

Shen, X. Y., Orson, F. M., \& Kosten, T. R. (2012). Vaccines against drug abuse. Clinical Pharmacology \& Therapeutics, 91(1), 60-70.

Stevenson, B. (2011). Drug policy, criminal justice, and mass imprisonment. Geneva: Global comission on drug policies.

Supriyanto, A. (2016). Islamic Guidance for Drug Addiction. Jurnal Konseling dan Pendidikan, 4(2), 98-104.

Supriyanto, A. (2017). Rehabilitation Counseling: Concept Assessment Guidance and Counseling For Drugs Abuse. In Prosiding Seminar Bimbingan dan Konseling (Vol. 1, No. 1, pp. 1930).

Supriyanto, A., \& Hendiani, N. (2018). Self Efficacy Scale For People With Drug Abuse Disorders. JKI (Jurnal Konseling Indonesia), 3(2), 5763.

Tiffany, S. T., Friedman, L., Greenfield, S. F., Hasin, D. S., \& Jackson, R. (2012). Beyond drug use: a systematic consideration of other outcomes in evaluations of treatments for substance use disorders. Addiction, 107(4), 709-718.

Volkow, N. D., Baler, R. D., \& Goldstein, R. Z. (2011). 
121 Jurnal Ilmiah Counsellia, Volume 8 No.2, November 2018| 114 -121

Addiction: pulling at the neural threads of social behaviors. Neuron, 69(4), 599602.

Volkow, N., \& Morales, M. (2015). The brain on drugs: from reward to addiction. Cell, 162(4), $\quad$ 712725.

Yoshimura, A., \& Higuchi, S. (2015). Danshukai and other support groups in addiction treatment. Textbook of Addiction Treatment: International Perspectives, 1057-1064.

Young, M. E., DeLorenzi, L. D. A., \& Cunningham, L. (2011). Using meditation in addiction counseling. Journal of Addictions \& Offender Counseling, 32(1-2), 58-71. 